\title{
PEMBARUAN HUKUM KELUARGA: WASIAT UNTUK AHLI WARIS (Studi Komparatif Tunisia, Syria, Mesir dan Indonesia)
}

\author{
Fatum Abubakar \\ STAIN Ternate, Jl. Dufa-dufa Pantai Kota Ternate \\ E-mail: o.daybsa@yahoo.co.id
}

\begin{abstract}
Abstrak: Hukum kewarisan Islam merupakan salah satu objek kajian dalam hukum Islam. Namun demikian, penerapan hukum kewarisan ini tidak selalu sama di setiap Negara Muslim. Tunisia, Syria, Mesir dan Indonesia merupakan Negara yang berpenduduk mayoritas Muslim, tetapi penerapan hukum kewarisan, terutama kepada siapa saja wasiat kewarisan itu dapat dilakukan dan berapa persen dari harta yang ditinggalkan dapat diwasiatkan kepada ahli waris, tidak sama persis. Inilah di antara beberapa pertanyaan yang dibahas dalam tulisan ini dalam hal penerapan hukum kewarisan pada keempat Negara Muslim tersebut.
\end{abstract}

Abtract: The Islamic law of inhreritance serves as one of the objects discussed in studies of Islamic law. However, the implementation of the Islamic law in the field of inheritance is not neccerally the same as that implemented in Muslim countires. The Muslim countries such as Tunis, Syria, Egypt and Indonesaia implement the Islamic law of inheritance but they do not possess the same understanding on the implementation of Islamic law of inheritance. The differencies lay on whoever elegible to receive the the property left by the dead persons and how many of the properties can be inherited; and whoever have the right to accept the inheritance from the dead person are among the questions discussed in this article in the respect of the implemenatiuon of Islamic law of inheritance in the four Muslim Countries.

Kata Kunci: hukum keluarga, wasiat, ahli waris, Negara Muslim 


\section{PENDAHULUAN}

Pembaruan ${ }^{1}$ hukum Islam telah dilakukan di negara-negara Islam, reformasi ini sangat mempengaruhi hukum Islam pada abad ke-19 dan ke-20 dan lebih berwawasan jauh ke depan dibandingkan dengan yang dilakukan sebelumnya, baik dorongan reformasi yang datang dari dalam tradisi Islam itu sendiri maupun yang dari luar tradisi Islam. ${ }^{2}$ Upaya besar pertama untuk mengkodofikasian aturan- aturan Islam dilakukan pada akhir abad ke-19 termasuk Indonesia meskipun dinilai lambat dibandingkan dengan negara-negara Islam lainnya, seperti Tunisia, Syiria dan Mesir.

Salah satunya dalam bidang hukum keluarga, mengenai wasiat untuk ahli waris. Hal ini dikarenakan hukum Islam (fikih) sebagai produk pemikiran ulama klasik dianggap sudah tidak dapat menjawab persoalan-persoalan kekinian. Di Indonesia, wasiat hanya diperuntukan bagi anak angkat dan bagi orang tua angkat yang disebut dengan ahli waris pengganti.

Sedangkan dalam kitab-kitab fikih klasik tidak dibahas persoalan ini, juga hadis Nabi yang mengatakan : "tidak ada wasiat bagi ahli waris" telah mengalami keberanjakan (keberanjakan horisontal), terbukti dengan negara yang akan penulis kemukakan ini, yakni : Tunisia, memberikan wasiat kepada ahli waris terbatas pada tingkat/generasi pertama,

${ }^{1}$ Pembaruan yang dimaksud di sini menurut Hasby ash-Shiddiq yakni pembaruan pemikiran tentang hukum Islam, adalah hal yang harus dikerjakan terus menerus agar tidak ketinggalan zaman. Dia menekankan, makna pembaruan hukum bukanlah dengan meninggalkan nas. Tetapi lebih pada memperbarui barang lama yang telah usang dengan mengembalikannya seperti keadaan semula yang sesuai dengan Alquran dan hadis yang murni, karena hukum Islam telah dilekati lumut. Lebih lanjut, perbedaan fikih antara satu masyarakat dengan masyarakat lain adalah satu konsekuensi logis yang bisa terjadi. Ini semua urgen bagi memungkinkan lahirnya "fikih yang berkepribadian Indonesia" yang berlaku bagi masyarakat Muslim Indonesia. Lihat, Nourouzzaman Shiddiq, Figh Indonesia, Penggagas dan Gagasannya (cet. ke-1; Yogyakarta : Pustaka Pelajar, 1997), h. 81-85.

${ }^{2}$ John. L.Esposito, Ensiklopedia Oxford Dunia Islam Modern, Jilid.5 (Bandung: Mizan, 2000), h. 209 
demikian juga dengan Syiria memberikan wasiat terbatas pada anak laki-laki atau cucu laki-laki dari garis laki-laki (keberanjakan diagonal).

Mesir mengesahkan warisan wajibah bagi ahli waris maupun bukan ahli waris yang dikehendaki, baik laki-laki maupun perempuan dan juga pemberian wasiat lebih dari sepertiga dengan syarat adanya kerelaan ahli waris setelah wafatnya pewaris, (keberanjakan vertikal).

Pembahasan mengenai wasiat ini sudah sering dibahas, baik dalam kitab fikih, buku maupun jurnal. Buku yang ditulis Alyasa Abubakar yang awalnya merupakan disertasinya, yang berjudul Ahli Waris Sepertalian Darah: Kajian Perbandingan terhadap Penalaran Hazairin dan Penalaran fikih Madzhab, membahas wasiat yang terdapat di negara-negara Muslim dan dibandingkan dengan pemikiran Hazairin. Selanjutnya buku Membaca Gelombang Ijtihad : Antara Tradisi dan Liberasi Karya M. Atho Mudzhar, terdapat pembahasan tentang wasiat wajibah yang terdapat dalam Kompilasi Hukum Islam (KHI) dan negara seperti Mesir, Sudan, Maroko dan Pakistan, namun pembahasannya terlalu singkat. Disusul dengan buku Pergumulan antara Hukum Islam dan Adat karya Ratno Lukito,juga karya A.Rofiq yang berjudul Hukum Islam di Indonesia.

Tulisan yang lebih komprehensif yang disertai analisis perbandingan ialah karya Tahir Mahmood, Family Law Reform in the Muslim World (1972) dan Personal Law in Islamic Countries (1987), yang dapat dijadikan acuan untuk karya-karya sesudahnya. Oleh karena itu, tulisan ini dapat dinilai orisinil karena tidak sekedar mengulang penelitian yang telah ada dan dalam tulisan ini juga akan dibahas masalah pengertian wasiat, dasar hukum, syarat-syarat dan batasan harta yang akan diwasiatkan, kemudian akan dideskripsikan beberapa negara Islam modern, sejarah berlakunya negara-nagara tersebut, baik dari segi politik maupun sosial-budaya, agar dapat dilihat 
reformasi hukum keluarga di negara-negara muslim tersebut, yang mengalami keberanjakan-keberanjakan dengan berbagai metode pembaruan. Baik intra doctrinal reform, extra doctrinal reform maupun regulatory dan modifikasi.

\section{PENGERTIAN, HUKUM, DAN DASAR HUKUM WASIAT}

Wasiat (Arab: al-wasiyyah) secara etimologis berasal dari kata washa yang berarti menyampaikan, dan bersambung. Dalam Alquran, kata wasiat yang seakar dengan wasiyyah memiliki beberapa arti di antaranya berarti menetapkan, sebagaimana terdapat dalam ayat; 3

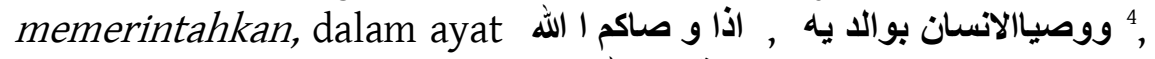
mensyari'atkan, dalam ayat Kata wasiat juga semakna dengan isha', asal kata dari awsha, yaitu pesan atau janji pada orang lain. Secara terminologis, wasiat adalah pesan atau janji sesorang kepada orang lain untuk melakukan sesuatu pebuatan baik ketika seseorang berwasiat masih hidup maupun setelah wafat). ${ }^{6}$

Ulama fikih mendefinisikan wasiat dengan, "penyerahan harta secara sukarela dari seseorang kepada pihak lain yang berlaku setelah orang tersebut wafat, baik harta itu berbentuk materi maupun berbentuk manfaat." Oleh sebab itu, terdapat perbedaan antara wasiat dan pemilikan harta lainnya seperti jual beli dan sewa menyewa, karena kepemilikan dalam dua bentuk akad yang disebutkan terakhir ini dapat berlaku semasa yang

${ }^{3}$ Q.S. al-An'am (6): 144.

${ }^{4}$ Q.S. Luqman (31): 14 dan Q.S. Maryam (19): 31.

${ }^{5}$ Q.S. al-Nisa (4): 12.

${ }^{6}$ Sayyid Sabiq, Fiqh al-Sunnah, Vol III (Beirut: Dār al-Fikr, 1995), h. 250; Ḥasan Ahmad al-Khațīb, al-Fiqh al-Muqāran (Mesir: Dār al-Taklîf, 1957), h. 5674.

${ }^{7} I$ Ibid., h. 257. 
bersangkutan masih hidup. Sedangkan wasiat, sekalipun akadnya dibuat ketika orang yang berwasiat masih hidup, hukumnya baru berlaku setelah orang yang berwasiat sudah wafat. Sebelum itu, akad wasiat tersebut tidak mempunyai efek apa pun dari segi pemindahan hak milik orang yang diberi wasiat. ${ }^{8}$

Sedangkan wasiat dalam Kompilasi Hukum Islam adalah pemberian suatu benda dari pewaris yang telah berumur sekurang-kurangnya berumur 21 tahun, berakal sehat dan tanpa ada paksaan kepada orang lain atau lembaga yang akan berlaku setelah pewasiat meninggal dunia. ${ }^{9}$

Dalam hukum suni, pemberi wasiat tidak boleh menggunakan warisan untuk menguntungkan orang-orang yang termasuk dalam pola tanpa wasiat, tetapi dalam hukum syi'ah hal ini dibolehkan, dengan alasan untuk menghindari tidak adanya harta menjelang kematian seseorang selama sakit ajal (marad almaut $)^{10}$, tidak boleh melepaskan hartanya.

Adapun wasiat mempunyai dasar hukum yang kuat dalam syari'at Islam. Dalil yang paling pokok tentang wasiat adalah ayat dalam QS. al-Baqarah (2): 180:

${ }^{8}$ Ibid, bandingkan dengan Wahbah al-Zuhailī, al-Fiqh al-Islāmī wa Adillatuh, Vol. VIII (Beirut: Dār al-Fikr, 1989), h. 8-9.

${ }^{9}$ Instruksi Presiden R.I. Nomor I Tahun 1991, Kompilasi Hukum Islam di Indonesia (Jakarta: Direktorat Pembinaan Badan Peradilan Agama Direktorat Jenderal Binbaga Depag RI Tahun 1998/1999), h.89.

${ }^{10}$ Marad al-maut dapat berlangsung setahun sebelum kematian, dan dihitung sejak kondisi yang menyebabkan kematian mulai terasa. Sebagai contoh dalam kasus khusus, ketika ada sejumlah ahli waris, maka hukum waris Islam akan menimbulkan pembagian harta waris menjadi bagian-bagian kecil sehingga tidak dapat digunakan. Untuk menghindari pembagian seperti itu, kaum Muslim dapat menggunakan berbagai cara; antara lain, menjadikan harta tanah sebagai wakaf sehingga harta itu keluar dari pola pewarisan tanpa wasiat. Lihat Esposito, Ensiklopedi ..., h. 155-156. 


$$
\begin{aligned}
& \text { كتب عليكم إذا حضر أحدكم الموت إن ترك خيرا ألوصية للوالدين والأقربين با } \\
& \text { لمعروف حقا على المتقين }
\end{aligned}
$$

"Diwajibkan atas kamu apabila seseorang di antara kamu kedatangan tanda-tanda maut, jika ia meninggalkan harta yang banyak, berwasiat untuk ibu bapak dan karib kerabatnya secara makruf ini adalah kewajiban orang yang bertakwa". ${ }^{11}$

Para ulama sepakat bahwa lafal kutiba dalam ayat di atas pada dasarnya menyatakan wajib, namun arti tersebut tidak dipegangi karena ada beberapa qarinah yaitu: ${ }^{12}$

- Ayat-ayat tentang kewarisan telah memberikan hak (saham) tertentu kepada orang tua dan anggota kerabat lainnya;

- Hadis yang menyatakan tidak boleh berwasiat kepada ahli waris;

- Kenyataan sejarah bahwa Rasulullah saw. dan kebanyakan sahabat tidak melakukan wasiat untuk anggota keluarganya.

Berdasarkan qarinah-qarinah ini, jumhur ulama menetapkan bahwa hukum wasiat kepada kerabat yang tidak mewarisi hanyalah sunah. Namun demikian, kewajiban wasiat tetap ada terhadap kewajiban-kewajiban yang belum ditunaikan seperti hutang yang tidak mempunyai bukti, zakat yang belum dikeluarkan atau kafarat yang belum dibayar. Kewajiban-

\footnotetext{
${ }^{11}$ Sebagian besar ahli hukum Islam setuju bahwa ayat ini di-nasakh ketika ayat-ayat Alquran yang mengatur kewarisan diturunkan. Namun demikian, ulama-ulama lain mengajukan argumen yang lebih kuat bahwa ayat tentang wasiat tersebut sesungguhnya hanya dihapus sebagaian saja, yaitu, hanya yang bersangkutan dengan kerabat dekat yang telah menjadi $a h l$ al-faraid (orang-orang yang menerima bagian tertentu dalam pembagian warisan). Ayat wasiat juga terdapat pada beberapa ayat yang lain, yakni : Q.S. al-Nisa (4): 11-12 mengenai pembayaran hutang si pewasiat, dan Q.S. alBaqarah (2): 181-182. Lihat Ratno Lukito, Pergumulan antara Hukum Islam dan Adat di Indonesia (Jakarta: INIS,1998), h. 85.

${ }^{12}$ Alyasa Abubakar, Ahli Waris Sepertalian Darah Kajian Perbandingan terhadap Penalaran Hazairin dan Penalaran Fikih Mazhab (Jakarta: INIS, 1998), h. 191.
} 
kewajiban ini bersifat ta'abbudi dan bukan qada'i. Maksudnya, orang tersebut akan berdosa jika tidak mengerjakannya, namun pengadilan atau keluarga yang masih hidup tidak mempunyai hak untuk "memaksakan" pelaksanaanya seamdainya tidak diucapkan. ${ }^{13}$

Reinterpretasi QS. 4:12 yang diusulkan juga mendorong untuk memperhatikan kembali hubungan antara QS. 2:180 dan 2:240 (ayat-ayat wasiat) dengan QS. 4:11-12 (ayat-ayat warisan). Vokalisasi yang ditawarkan sepenuhnya tidak menghadapai masalah dari segi sintaksis yang dihadapi Thabari: subjek ganda terpisah rajulun ...au imratun hilang ; kata kalalah sekarang muncul sebagai objek langsung dari kata transitif yuritsu; kata ganti dalam frase preposisional wa lahu tidak lagi merujuk ke subjek ganda ; dan kata kerja yushi yang terikat dengan kata benda rajulun memiliki arti yang lebih baik daripada kata kerja pasif impersonal yusha. ${ }^{14}$

Ada alasan signifikan mengapa muncul perdebatan di kalangan pembaca Alquran tentang cara yang tepat dalam membaca QS.(2):12, dan ini dapat dipahami bahwa perdebatan itu melibatkan dua kelompok : mereka yang setiap ada yuritsu/imra'atan/yushi, dan mereka yang mendukung yuratsu/imra'atun/yusha. Indikasi yang diberikan Umar bahwa jika makna kalalah telah diketahui para wanita, maka mereka akan "membicarakannya di kediaman mereka", mungkin dapat dikaitkan dengan pernyataan bahwa kalalah sebenarnya adalah sebuah istilah untuk kerabat perempuan, dan bahwa QS.4:12 berisi tentang penunjukan seorang menantu (perempuan) atau isteri sebagai ahli waris.

${ }^{13}$ Ibid.

${ }^{14}$ David S. Powers, Studies in al-Qur'an and Hadith: The Formation of the Islamic Law of Inheritance, terj. Arif Maftuhin (cet. ke-1; Yogyakarta: LKiS, 2001), h. 63. 
Dalam bahasa David S. Power ${ }^{15}$-serangkaian anekdot yang menunjukan signifikansi kebingungan wala tentang makna QS. An-Nisa (4):12 dan 176. Anekdot-anekdot berisi sejumlah petunjuk yang menunjukkan pembacaan alternatif tentang makna ayat itu dalam kaitannya dengan QS. an-Nisa (4):176. Ia berkeyakinan bahwa pembacaan alternatif tersebut mencerminkan makna asli kedua ayat itu didasarkan pada tiga alasan utama:

Pertama, teks consonantal (teks gundul) Alquran sendiri, argumen-argumennya kebanyakan adalah argumen gramatis dan linguistis. Pembacaan yuritsu/imra'atan/yushi merupakan model yang lebih sederhana, pembacaan yang lebih tidak dipaksakan atas QS. an-Nisa (4):12 daripada pembacaan tradisional.

Kedua, adanya hadis-hadis tandingan yang dilupakan; argumen-argumennya adalah argumen historis. Anekdot tadi mengindikasikan bahwa selama abad pertama pascawafatnya Nabi Muhammad, diskusi tentang QS. An-Nisa' (4):12 dan 176 sangat lebih terbuka daripada tahun-tahun sesudahnya.

Ketiga, kontrol yang dilakukan oleh para sarjana Muslim terhadap cara membaca Alquran yang tepat. Setelah interpretasi tradisional atas QS.4;12 dan QS.4:176 dipersiapkan berdasarkan ijma', keberadaan yuritsu/imra'atan'yushi inilah yang diabaikan, dan akhirnya dilupakan.

Lebih tepatnya, pembacaan yushi dan yuritsu diperbolehkan beredar, tetapi mereka beredar dalam suatu keadaan di mana mereka tidak menimbulakan ancaman terhadap pembacaan yang diterima. Menurut Ibnu Mujahid, sebagaimana dikutip Powers bahwa secara rutin, pembacaan ini disebutkan dalam hampir seluruh kitab tafsir Alquran dan dikutip dengan kepercayaan penuh dalam buku-buku koleksi standar qira'ah sab'ah. ${ }^{16}$

${ }^{15}$ Ibid., h. 56-59.

${ }^{16}$ Ibid. 
Dengan demikian, dampaknya terhadap hukum wasiat, atau jika dapat dikatakan hasilnya adalah pembatasan sepertiga sebenarnya diintrodusir dengan tujuan menciptakan keseimbangan antara perolehan ahli waris testamentair (minumum dua pertiga), satu pihak, dengan para ahli wasist (maksimum sepertiga) di lain pihak. Oleh karena itu, bukanlah akibat perubahan kehendak Allah, tetapi perubahan persepsi mengenai makna firman Allah. Adapun dasar hukum wasiat di antaranya adalah sabda Rasulullah saw. :

\begin{abstract}
"Sesungguhnya Allah bersedakah kepada kamu tatkala kamu akan menghadapi kematian (untuk berwasiat sepertiga dari harta kamu". (HR. al-Bukari dan Muslim dari lima orang sahabat, yaitu : Abu Hurairah, Abu ad-Darda, Mu'az bin Jabal, Abu Bakar ash-shiddiq, dan Khalid bin Ubaid). Dalam riwayat lain dikatakan bahwa Sa'ad bin Abi Waggas: “ Sepertiga, seperti itu pun telah banyak (untuk diwasiatkan). Sesungguhnya meninggalkan ahli waris dalam keadaan kaya lebih baik dari pada mereka meminta-minta kepada orang lain". (HR. al-Jamaah; mayoritas perawi hadis). ${ }^{17}$
\end{abstract}

Adapun hukumnya dilihat dari segi harus dilaksanakan atau harus ditinggalkan wasiat itu, maka para ulama berbeda pendapat. Pendapat-pendapat tersebut terbagi ke dalam pada tiga kategori ${ }^{18}$ yaitu:

\title{
Pendapat Pertama
}

Pendapat ini memandang bahwa wasiat itu wajib bagi setiap orang yang meninggalkan harta, baik harta itu banyak maupun sedikit. Pendapat ini dikatakan oleh az-Zuhri dan Abu Mijlaz. Juga Ibnu Hazm yang meriwayatkan wajibnya wasiat itu dari Ibnu Umar, Thalhah, az-Zubair, Abdullah bin Abu Aufa, Thalhah bin

${ }^{17}$ Muslim, Al-Jāmi' al-Ṣaḥiḥ, 5 : 71. Abdul Aziz Dahlan, Encyclopedi Hukum Islam, jilid 6 (Jakarta: PT. Ichtiyar Baru Van Hoeve, 1997), h. 1926. Imām Mālik, Muwațta' al-Imām Mālik, terj. Adib Bisri Musthofa, dkk., jilid II (Semarang: CV. Asy-Syifa, 1992), h. 435-438.

${ }^{18}$ Sabiq, Fiqh al-Sunnah ..., h. 220-221. 
Mutharrif, ath-Thawus dan asy-Sya'bi, mereka menggunakan firman Allah dalam surat al-Baqarah (2):180 tersebut di atas.

\section{Pendapat Kedua}

Pendapat ini memandang bahwa wasiat kepada kedua orang tua dan karib yang tidak mewarisi dari mayit itu wajib hukumnya. Pendapat ini dikatakan oleh mazhab Masruq, Iyas, Qatadah, Ibnu Jarir dan az-Zuhri.

\section{Pendapat Ketiga}

Yaitu pendapat empat orang imam dan aliran Zaidiyah yang menyatakan bahwa wasiat itu bukanlah kewajiban atas setiap orang yang meninggalkan harta (pendapat pertama), dan bukan pula kewajiban terhadap orang tua dan kerabat yang tidak mewarisi (pendapat kedua), tetapi wasiat itu berbeda-beda hukumnya menurut keadaan. Oleh karena itu, hukum wasiat kadang-kadang wajib, sunah, haram, makruh dan jaiz (boleh). ${ }^{19}$

\section{RUKUN, SYARAT, DAN BATASAN WASIAT}

Terdapat perbedaan pendapat ulama fikih dalam menentukan rukun wasiat. Mazhab Hanafi menyatakan bahwa rukun wasiat hanya satu, yaitu ijab ${ }^{20}$, karena menurut mereka, wasiat adalah akad $^{21}$ yang hanya mengikat pihak yang berwasiat, sedangkan bagi pihak penerima wasiat, akad itu tidak bersifat

${ }^{19}$ Fathurrahman Jamil, Mimbar Hukum: Aktualisasi Hukum Islam, Nomor 38 Tahun IX (Jakarta: al-Hikmah dan Direktorat Pembinaan Badan Peradilan Agama Islam, 1998), h. 8-9.

${ }^{20}$ Pernyataan pemberian wasiat dari pemilik harta yang akan wafat.

${ }^{21}$ Sifat akad wasiat, ulama fikih menyatakan bahwa apabila wasiat telah memenuhi rukun dan syaratnya, wasiat itu sah dan harus dilaksanakan, terhitung sejak wafatnya al-mūṣī. Namun demikian, mereka juga sepakat bahwa akad wasiat itu sifatnya tidak mengikat, artinya, al-mūṣi boleh membatalkan wasiatnya itu, selagi ia masih hidup, kapan saja ia mau, baik membatalkan sebagian atau seluruhnya, baik dalam keadaan sehat maupun sakit. 
mengikat. Selain itu juga dibutuhkan Kabul, ${ }^{22}$ menurut salah satu tokoh madzhab Hanafi Ibnu Abidin (w. 1252 H).

Jumhur ulama fikih, menyatakan rukun wasiat terdiri atas ${ }^{23}$ : (1) al-musi (orang yang berwasiat ), (2) al-musa lah (yang menerima wasiat), (3) al-musa bih (harta yang diwasiatkan), (4) siqah (ijab kabul).

Sesuai dengan rukun wasiat yang dikemukakan di atas maka ulama fikih menetapkan syarat-syarat wasiat, yaitu; (1) alMusi, syaratnya adalah (a) Orang yang berwasiat itu cakap hukum atau baliq, (b) Wasiat itu dilakukan secara sadar dan sukarela, (c) Orang yang berwasiat itu tidak mempunyai hutang yang jumlahnya sebanyajk harta yang akan ditinggalkannya; (2) almusa lah, syaratnya ditujukan pada pribadi atau lembaga, adalah (a) Benar-benar ada, (b) Identitasnya jelas, (3) Orang atau lembaga yang cakap menerima hak/milik, (d) Penerima wasiat itu bukan orang yang membunuh pemberi wasiat, jika wafatnya karena terbunuh, (e) Penerima wasiat itu bukan kafir harbi, (f) Wasiat itu tidak dimaksudkan untuk sesuatu yang merugikan umat Islam atau sesuatu maksiat; (3) al-musa bih, syarat harta yang di wasiatkan yakni: (a) Yang di wasiatkan itu sesuatu yang bernilai dalam syarak bukan yang tidak bersyarak, seperti minuman keras dan babi, (b) Yang di wasiatkan itu sesuatu yang bisa dijadikan milik, baik berupa materi atau manfaat, (c) Yang di wasiatkan itu adalah milik al-musi, ketika berlangsung wasiat, (d) Harta yang di wasiatkan itu tidak melebihi dari sepertiga harta al-musi: dan (4) ijab dan kabul, syarat yang berhubungan dengan siqah wasiat, ulama fikih menetapkan bahwa ijab kabul yang diperlukan harus

\footnotetext{
${ }^{22}$ Pernyataan penerimaan wasiat dari orang yang menerima harta yang diberi sipewasiat menjelang wafat.

${ }^{23}$ Taqiyuddin Abi Bakr ibn Muhammad, Kifäyah al-Akhyār, terj. Muhamad Rifa'i, dkk. (Semarang: Toha Putra, 1978), h. 264. Bandingkan dengan Al-Mahāmiy Subhị Mahmasānī, Al-Mabādi' al- Syar'iyyah wa al-Qānūniyyah fī al-Hajr wa an-Nafaqāt wa al-Mawāris wa al-Wașiyyah (Beirut: Dār al-'Ilm alMalāyin, 1967), h. 157-179
} 
jelas dan harus sejalan. Siqah ijab dan kabul yang digunakan untuk mengungkapkan wasiat itu bisa disampaikan secara lisan, tulisan maupun isyarat yang dapat dipahami.

Adapun wasiat melalui isyarat yang dipahami, menurut ulama mazhab Hanafi dan Hanbali hanya bisa diterima apabila orang yang berwasiat itu bisu atau tidak bisa menuli dan membaca baca. Akan tetapi, ulama mazhab Maliki dan Syafi'i berpendapat bahwa wasiat tetap sah walaupun melalui isyarat yang dapat dipahami, meskipun orang yang berwasiat itu mampu berbicara dan mampu untuk membaca dan menulis. ${ }^{24}$

Dalam hal orang yang bakal menerima wasiat itu orang lain, jumlah harta yang boleh diwasiatkan hanya sepertiga dari harta si pewasiat setelah dikurangi hutang-hutangnya. Jumlah ini adalah jumlah maksimum yang diizinkan oleh syari'at Islam $^{25}$ sesuai dengan hadis sebagaimana dikutip di atas.

Jumhur ulama berpendapat bahwa sepertiga itu dihitung dari semua harta yang ditinggalkan oleh pemberi wasiat. Sedang Malik berpendapat bahwa sepertiga itu dihitung dari harta yang diketahui oleh pemberi wasiat, bukan yang berkembang tetapi tidak diketahui. ${ }^{26}$

Menurut Ibnu Hazm, tidak ada ketentuan tentang jumlah atau perbandingan harta yang diwasiatkan, hal ini diserahkan kepada pertimbangan dan ketulusan masing-masing, asal masih dalam batas sepertiga warisan (harta). Namun demikian, ia memberi batas minimum tentang jumlah orang yang akan menerimanya. Jika kerabat yang tidak mewarisi tersebut banyak, ia harus berwasiat sekurang-kurangnya kepada tiga orang. Jika ia berwasiat kepada orang yang bukan kerabat, dua pertiga dari wasiatnya tersebut harus dialihkan kepada kerabat dan hanya

\footnotetext{
${ }^{24}$ Ibid.

${ }^{25}$ Ibid., h.180

${ }^{26} \mathrm{Ibn}$ Muhammad, Kifāyah ..., h. 232.
} 
sepertiga yang diserahkan sesuai dengan "wasiat asli". ${ }^{27}$ Yang berkewajiban melaksanakan "mengubah" wasiat tersebut adalah ahli waris atau pemegang wasiat.

Orang yang berwasiat itu adakalanya mempunyai ahli waris dan adakalanya tidak mempunyai ahli waris. Bila mempunyai ahli waris, ia tidak boleh mewasiatkan lebih dari sepertiga, seperti yang telah disebutkan. Apabila ia mewasiatkan lebih dari sepertiga, wasiatnya tidak dilaksanakan kecuali atas izin dari ahli waris dengan dua syarat $;^{28}$ sebagai berikut: (1) Agar permintaan izin dari ahli waris itu dilaksanakan sesudah orang yang berwasiat itu wafat, sebab sebelum ia wafat, orang yang memberi izin itu belum mempunyai hak, sehingga izinnya tidak menjadi pegangan. Jika ahli waris mengizinkan pada waktu orang yang berwasiat masih hidup, mungkin mencabut kembali wasiatnya bilamana ia menginginkannyan. Dan jika ahli waris memberikan izin setelah orang yang berwasiat itu wafat, wasiat itu dapat dilaksanakan; dan (2) agar orang yang memberi izin itu mempunyai kompetensi yang sah, tidak dibatasi karena kebodohan dan kelalaian, pada waktu memberikan izin. Jika orang yang berwasiat tidak mempunyai ahli waris maka dia pun tidak boleh mewasiatkan lebih dari sepertiga.

Dengan demikian sudah jelas bahwa apabila pewasiat mewasiatkan hartanya lebih dari sepertiga maka wasiat itu harus mendapatkan persetujuan ahli warisnya, sebaliknya jika tidak ada persetujuan maka wasiat itu hanya berlaku sepertiga saja.

\footnotetext{
${ }^{27} \mathrm{Ibnu}$ Hazm, al-Muhalla, h.134. selanjutnya dia mengatakan orang yang berhak atau seorang yang wajib berwasiat kepada ayah ibu serta keturunan ayah ibu, baik yang melalui dia sendiri maupun yang melalui saudarasaudaranya sekiranya ada yang tidak mewarisi.

${ }^{28} \mathrm{Ibn}$ Muhammad, Kifäyah ..., h. 233. Sajuti Thalib, Hukum Kewarisan Islam di Indonesia (cet. ke-5; Jakarta: Sinar Grafika, 1995), h. 104-110. Bandingkan dengan Hazairin, Hukum Kewarisan Bilateral menurut Qur'an dan Hadis, buku ke-2 (Jakarta : t.p., 1964), h. 31.
} 


\section{WASIAT DI NEGARA-NEGARA ISLAM MODERN}

\section{Tunisia}

Tunisia adalah salah satu negara yang menanggung sejumlah problem politik, ekonomi, social, hukum dan sebagainya. Secara politik, upaya reformasi ini tergantung kepada dukungan pihak ulama, yang mana Khayr al-Din berusaha mempengaruhi mereka agar menerima teknik-teknik pemerintahan Eropa. Argumentasinya dilandaskan pada term politik Islam klasik tentang pertanggungjawaban pemerintahan terhadap rakyatnya. Selain ulama, ada tokoh lainnya yang berusaha mereformasi untuk memperkuat negara-yang berlangsung pada tahun 1873-1877-dengan berusaha memperkecil anggaran belanja publik, memperkecil kebocoran dalam pengumpulan pajak, dan mereformasi adminidtrasi urusan agama. Di bawah kepemimpinanya pemerintah membentuk kantor-kantor baru untuk pengelolaan harta wakaf dan mereorganisir pengadilan Muslim, khususnya untuk menghadapi tuntunan persamaan bangsa Eropa. Terakhir, program reformasi meliputi pembentukan sebuah penerbitan percetakan pemerintah yang menerbitkan buku-buku teks untuk kepentingan pelajar Sadiqi untuk mereproduksi naskah-naskah klasik hukum Islam. Hal ini berlangsung sampai khayr al-Din diberhentikan dari jabatannya. $^{29}$

Sejak tahun 1880-an sampai 1930 -an para pemuka Tunisia muncul kebarisan terdepan, selama satu decade lebih Partai Destour dipimpin oleh beberapa keluarga konservatif, hingga tahun 1932 mereka menuntut kemerdekan bagi Tunisia dan pada tahun 1934 partai ini kemudian diambil alih oleh Partai Neo-

${ }^{29}$ Ira M. Lapidus, Sejarah Sosial Umat Islam, terj. Ghufron. A. Mas'ad, Bag. III (cet. ke-1; Jakarta: Raja Grafindo Parsada, 1999), h.228-229; John L. Esposito, The Oxford Encyclopedia of The Modern Islamic World, IV (New York-Oxford : Oxford University, 1991), h. 235-240 ; Pj. Bearman (Eds.), The Encyclopedia of Islam, X, New Edition (Leiden: Brill, 2000), h. 651-663. 
Destour yang melanjarkan pertempuran selama 12 tahun, yang berakhir dengan kemerdekaan dan pembentukan pemerintahan Tunisia yang merdeka segara dilanjutkan dengan konsolidasi kekuasaan Bourquiba dan ditetapkan ia sebagai Kepala Negara pertama dan melalui konstitusi tahun 1959 mempercayakan seluruh kekuasaan kepada presiden. ${ }^{30}$

Madzhab Maliki berpengaruh besar di Tunisia selama pemerintahan Usmani, wilayah tersebut sudah mengenal Madzah Hanafi. Oleh karena itu, penerapan hukum-hukum keluarga merupakan gabungan madzab Hanafi dan Maliki yang masingmasing diwakili oleh qadinya dari masing-masing mazhab tersebut yang diterapkan di Pengadilan Agama.

Sejak tahun 1883 hingga akhir abad pertengahan Tunisia tetap di bawah politik Perancis sehingga selama itu pula kultur hukum di Tunisia sangat dipengaruhi oleh hukum Barat. Misalnya hukum tata negara, pidana, perdata yang diberlakukan di Tunisia hingga tahun 1956, pada dasarnya mengikuti prinsip hukum yang berlaku dari Perancis, seperti hukum tata negara.

Ketika Tunisia memperoleh kemerdekaannya pada tahun 1956, berdasarkan UU tahun 1957 Tunisia menjadi Republik Demokrat. Setelah itu Tunisia berhak melegalkan undang-undang sebelum merdeka, seperti hukum perdata dan pidana dengan badan legislasi.

Pada akhir tahun 40-an, dari abad ini telah beberapa kali hukum utama Tunisia menganggap bahwa peraturan madzab Hanafi-Maliki adalah sebuah undang-undang hukum keluarga yang baru dapat dibentuk untuk menyesuaikan dengan perubahan social yang terjadi pada negara tersebut dan untuk tujuan ini sekelompok pakar hukum telah mempersiapkan draf undang-undang dengan memadukan kedua mazhab tersebut, kemudian mempublikasikannya dengan judul La-i' hat Majallat

${ }^{30} \mathrm{Ibid}$. 
al-Ahlamal al-Syar'iyah (Draft Code of Shari'ah Laws). Selanjutnya pemerintah Tunisia membentuk suatu komite di bawah pengawasan Syekh al-Islam negara yaitu Muhammad Ja'id pada saat itu untuk memberlakukan undang-undang secara resmi. Syaikh Universitas Zaituna juga ikut berpartisipasi dalam komite tersebut. Dengan menggunakan sumber-sumber yang diperoleh dari hasil-hasil komite itu (La'ihat) dan hukum keluarga ala Egypt, Yordania, Syiria dan Turki Utsmani. Komite tersebut mengajukan draft undang-undang hukum keluarga kepada pemerintah dan akhirnya diberlakukanlah undang-undang tersebut pada tahun $1956 .{ }^{31}$

Undang-undang tersebut memuat 170 pasal yang ditulis dalam 10 jilid yang dianggap komprehensip, meskipun belum memuat undang-undang kewarisan. Dalam hal wasiat, Tunisia yang juga mengikuti langkah Mesir, membuat suatu aturan yang terdapat pada pasal 192 hukum status personal Tunisia 1956, yang berbunyi: memperbolehkan anak-anak dari anak laki-laki atau anak perempuan yang meninggal terlebih dahulu untuk menerima bagian orang tuanya jika ia masih hidup-dengan maksimum sepertiga harta warisan. ${ }^{32}$

\section{Syria}

Penduduk Muslim Syria terdiri atas mayoritas Sunni dan empat sekte Syi'ah minoritas. Angka yang pasti tidak tersedia tetapi perkiraan-perkiraan yang diperoleh menempatkan penduduk Sunni tersebar diseluruh negeri secara kasar mencapai angka 70\%. Posisi Islam dalam masyarakat Syria telah berubah secara mendasar pada masa-masa modern. Pada awal abad ke 19, kaum elit politik dan social di kesultanan Usmaniah

\footnotetext{
${ }^{31}$ Tahir Mahmood, Personal Law in Islamic Countries, (History, Text and Comparative Analysis) (New Delhi: Academy of Law and Relegion, 1987), h. 152

${ }^{32}$ Ibid., h. 163; Herbert J. Liebesny, The Law of The Near and Middle East: Readings, Cases, and Materials (Albany: State University of New York Press, 1975), h. 187-188.
} 
mempersatukan institusi-institusi, simbol-simbol kaum ulama Islam. Pada paro kedua abad ke 20, kecenderungan sekuler mendominasi Syria, dan gerakan-gerakan pemulihan kedudukan tertinggi Islam menjadi alasan pembangkangan politik. Selama era Usmaniyah (1517-1918), para sultan melegitimasi otoritas mereka dengan mengklaim menjalankan pemerintahan sesuai dengan Islam. ${ }^{33}$

Pada 1841 kesultanan usmani cenderung sekuler dan mendukung Eropa sehingga Syria tidak lagi tunduk pada hukum Islam, sampai akhir perang dunia I kesultanan Usmani hancur dan di Syria muncul nasionalisme Arab yang dipimpin oleh Amir Faisal untuk mengusir kekuasaan asing terutama Prancis. ${ }^{34}$ Sehingga semua penduduk Syria yang terdiri atas bermacammacam agama bersatu.

Pada saat kemerdekaan 1946-1963 politik di Syria mengalami serangkaian kudeta militer, kabinet-kabinet yang berumur singkat, hubungan dengan Mesir yang singkat, dan kekuatan politik yang dinamis yaitu munculnya partai sosialis Arab Ba'ath, persatuan sosialis arab Syria, unionis sosialis, partai sosialis arab dan partai komunis Syria. ${ }^{35}$

Selama dalam kekuasaan usmani, di Syria berlaku sistem peradilan dan sistem hukum Usmani. Disamping itu berlaku juga code civil 1876 dan hukum hak-hak keluarga 1917 (Law on Family Right). Setelah Usmani hancur, Syria berada dalam kekuasaan bangsa Eropa (Perancis dan Inggris), sehingga secara perlahan-

${ }^{33}$ Esposito, The Oxford ..., h. 156-159.

${ }^{34}$ Ibid.; Don Peretz, The Middle East Today (New York: Praeger, 1986), h. 397-399.

${ }^{35}$ M. Lapidus, Sejarah Sosial ..., h. 179. Partai Ba'aś yang berkuasa di Syria dan Irak, mendukung persatuan Arab tetapi melepaskan cabang-cabang partai ini memerintah dua negara tersebut dan keduanya saling bermusuhan. Masingmasing rezim mengidentifikasi nasionalisme Arab dengan pemenuhan terhadap tujuan-tujuan sosialis dari negaranya sendiri. Lebih jauh, nasionalisme Arab selalu bersandar pada sebuah pola hubungan yang ambivalen terhadap nasionalisme negara. Ibid. 
lahan sistem hukum dan peradilan Syria menjadi sekuler dan hukum Anglo Perancis telah memberi pengaruh yang besar terhadap hukum perdata dan pidana. ${ }^{36}$ Meskipun demikian Hukum Islam (Islamic Personal Law) tetap dijaga dan dipertahankan

Setelah merdeka Syria mulai memperlakukan nasionalisasi dan reformasi sistem hukum. Sejumah UU diberlakukan baik dalam perdata tahun 1953 (UU Status Personal), hukum pidana tahun 1950 dan hukum dagang tahun 1949.

Sejumlah pasal undang-undang 1953, secara signifikan diganti dengan UU 1975. Amandemen tersebut ditambah menjadi 22 pasal yang telah disetujui oleh Parlemen Syria. ${ }^{37}$ Adapun tambahan pasal yang dimaksud, antara lain tentang wasiat yang terdapat pada:

Pasal 232 : tidak ada wasiat yang dibolehkan bagi keturunan kecuali hanya pada golongan pertama, dimana golongan ini adalah golongan yang terhalang mendapat harta warisan.

Pasal 238: (1) wasiat kepada bukan ahli waris seharusnya tidak boleh lebih dari sepertiga harta peninggalan, setelah pembayaran hutang jika ada. Meskipun tanpa persetujuan dari ahli waris. (2) Wasiat tidak boleh melebihi batas maksimal dari sepertiga. (3) Yang didahulukan adalah pembayaran hutang baru kemudian wasiat. (4) Wasiat untuk semua harta yang ada dibolehkan jika memang tidak ada ahli waris yang lain. ${ }^{38}$

Pasal 257 : Jika seorang meninggal, meninggalkan seorang putra dan punya anak (cucu pewaris) maka cucu tersebut berhak mengambil bagian dari ayah mereka dan memungkinkan mendapat sepertiga, asalkan sesuai dengan kondisi sebagai berikut : (a) Wasiat wajibah bagi cucu seharusnya sama seperti bagian dari bapaknya, yang penting tidak lebih dari sepertiga harta yang lazim terjadi. (b) Cucu seharusnya tidak diberikan harta melalui wasiat wajibah jika mereka dapat mewarisi kekuasaan orang tuanya (ayahnya). (c) Wasiat wajibah diberikan kepada cucu dan anak dari cucu satu orang dengan sistem 2:1. ${ }^{39}$

\footnotetext{
${ }^{36}$ Mahmood, Personal ..., h. 139-140

${ }^{37}$ Ibid., h. 141.

${ }^{38}$ Ibid., h. 148.

${ }^{39}$ Ibid., h.149.
} 
Dengan demikian dalam perundang-undangan Syria, cucu yang berhak menerima wasiat wajib hanyalah melalui garis lakilaki. Jadi cucu melalui anak perampuan tidak mendapat apa-apa. Dan jumlah harta yang diwasiatkan tidak lebih dari sepertiga. ${ }^{40}$

\section{Mesir}

Republik Arab Mesir yang merupakan tanah kelahiran mazhab syafi'i, yang sekarang berada dibawah sistem pemerintahan yang telah mengalami modifikasi (modern). Namun belakangan setelah menjadi bagian propinsi kerajaan Ottoman Turki, Mesir mengadopsi sistem hukum yang bersumber dari madzhab Hanafi. ${ }^{41}$ Dalam sejarah modernisasi Mesir ketika masih dijajah pada tahun 1874 yang masih diperintah oleh suatu sistem kerajaan. Yang telah mendapatkan kemerdekaannya yang mencapai gemilang. Perhatian pertama terfokus pada administrasi hukum yang dijalani sejak tahun 1875-1889 yang dimaksudkan untuk membangun pengadilan nasional. Dalam jangka tujuh tahun perkembangan Mesir tidak lepas dari pengaruh Inggris dan pada masa-masa sekarang masih mengikuti sistem hukum Eropa. ${ }^{42}$

Pada abad-abad berikutnya ahli hukum dan sarjana Mesir ${ }^{43}$ mengadakan revolusi social dalam negeri dalam bidang hukum melalui diskusi untuk mengajukan draf hukum. Berdasarkan

${ }^{40}$ Lain halnya yang terjadi di Irak anak perempuan mengambil semua harta warisan karena cucu dan saudara terhijab oleh anak. Di Pakistan, anak perempuan mendapat sepertiga dan cucu laki-laki garis perempuan pun mendapat sepertiga sebagai ahli waris pengganti dari ibunya. Dan saudara mendapat asaba. Adapun Maroko persis sama dengan di Tunisia. Seperti tersebut di bagian awal.

${ }^{41}$ Mahmood, Family Law Reform in the Muslim World (Bombay: NM. Tripthi, 1972), h. 48.

${ }^{42}$ Tahir Mahmood, Personal ..., h. 27; Esposito, Ensiklopedi ..., h. 49. B. Lewis, CH. Pellat dan J. Schact, The Encyclopedia of Islam, Vol. II (Leiden: EJ Brill, 1965), h. 647-648; Don Peretz, The Middle ..., h. 227-231.

${ }^{43}$ Ahli hukum dan sarjana Mesir antara lain; Rasyid Ridha, Muhamad Abduh, Mustafa al-Maragih dan sarjana al-Azhar lainnya. Ibid., h. 28 
keputusan Mahkamah Agung dalam "Jihan Law" konstitusi masyarakat harus mengikuti dan mematuhi hukum tersebut. Kemudian, tepatnya pada bulan Desember 1985 sebuah hukum baru diamandemen yang berasal dari undang-undang yang lama pada tahun 1920-1929.

Salah satu bagian dari pembaruan hukum adalah hukum keluarga, sebagaimana yang dinyatakan oleh pembaharu terdahulu, bahwa hukum keluarga selama ini sudah tidak sesuai lagi dengan prinsip-prinsip yang diambil dari mazhab fikih, terlebih jika diperhadapkan dengan zaman yang modern. Untuk itu harus ada perombakan secara radikal, terbukti pernah ada sistem hukum tidak resmi yang disusun oleh hakim Qudri Pasha, namun tidak mengikat. ${ }^{44}$

Mesir sebagai negara pertama melakukan pembaruan hukum secara total dan telah menghasilkan beberapa produk perundang-undangan, antara lain; UU No. 77 tahun 1943 tentang kewarisan intestato, UU No. 71 tahun 1946, tentang kewarisan testamentary. Kedua undang-undang ini didasarkan pada prinsipprinsip hukum tentang kewarisan dan wasiat yang telah ada dalam kitab fikih. Tetapi UU ini juga telah mengenalkan beberapa ketetapan baru untuk kepentingan ahli waris tertentu yang dalam kitab fikih hanya memperolah bagian sedikit atau tidak memperoleh bagian sama sekali. Adapun materi pokok pembaruan hukum keluarga dalam UU No. 100 tahun 1985 (amandemen), terkhusus ketetapan tentang warisan wajib/wasiat wajib bagi keturunan anak yang meninggal lebih dahulu dari pada pewaris terdapat pada pasal 76-79.

Pasal 76: sekiranya seorang pewaris (al-mayyit) tidak berwasiat untuk keturunan dari anak yang telah meninggal sebelum dia (pewaris), atau meninggal bersama-sama dengan dia, sebesar saham yang seharusnya diperoleh anak itu dari warisan, maka keturunan tersebut akan menerima saham itu melalui wasiat (wajib) dalam batas sepertiga harta

${ }^{44}$ Ibid., lihat, Ian Edge dalam Nicholas Heer, (Ed.), Islamic Law and Jurisprudensi (Wangshinton: University of Wangshinton Press, 1990), h. 164. 
dengan syarat (a) keturunan tersebut tidak mewarisi (b) orang yang meninggal (pewaris) belum pernah memberikan harta dengan cara-cara yang lain sebesar sahamnya itu. Sekiranya telah pernah diberi tetapi kurang dari saham yang seharusnya ia terima, maka kekurangan dianggap sebagai wasiat wajib.

Wasiat ini menjadi hak keturunan derajat pertama dari anak laki-laki dan perempuan serta keturunan seterusnya menurut garis laki-laki, setiap derajat menghijab keturunannya sendiri tetapi tidak dapat menghijab keturunan dari yang lainnya. Setiap derajat membagi wasiat tersebut seolah-olah sebagai warisan dari orang tua mereka itu.

Pasal 77: kalau seseorang memberi wasiat lebih dari saham yang seharusnya diterima, maka kelebihan itu dianggap sebagai wasiat ikhtiariah. Sekiranya kurang, kekurangan itu disempurnakan melalui wasiat wajib. Kalau berwasiat kepada sebagian keturunan dan meninggalkan sebagian yang lain, maka wasiat wajib diberlakukan kepada semua keturunan dan wasiat yang ada dianggap berlaku sepanjang sesuai dengan ketentuan dalam pasal 76 diatas. ${ }^{45}$

Penjelasan resmi undang-undang tersebut menyatakan bahwa dorongan memasukkan pasal-pasal tadi kenyataan seringnya munculnya pengaduan bahwa anak-anak (yatim) yang kematian ayah tidak mendapat warisan karena terhijab oleh saudara-saudara ayahnya. Walaupun seseorang pada galibnya berwasiat untuk cucu yang yatim itu, tetapi ajal yang tidak diduga menyebabkan wasiat itu tidak sempat terucapkan. ${ }^{46}$

Coulson menamakan pengambilan undang-undang Mesir ini sebagai quasi ijtihad. Mungkin ia menggunakan istilah tersebut karena isi aturan ini merupakan hal yang baru, yang tidak ditemukan dalam salah satu pendapat ulama awal, tetapi tidak dapat disebut sebagai ijtihad penuh karena walaupun hanya dari segi nama tetap dikaitkan dengan pendapat para ulama awal. ${ }^{47}$

${ }^{45}$ Mahmood, Personal ..., h. 46-47.

${ }^{46}$ Abubakar, Ahli Waris Sepertalian Darah ..., h. 194.

${ }^{47}$ Coulson, Hukum Islam dalam Persfektif Sejarah, Terj. Hamid Ahmad (cet. ke-1; Jakarta: P3M, 1987), h. 237. Bandingkan dengan pendapat Abu Zahrah, menambahkan kenyataan, sering anak-anak yang kematian ayah tersebut hidup dalam kemiskinan sedang saudara-saudara ayahnya hidup dalam kecukupan. Anak yatim tersebut menderita karena kehilangan ayah dan 


\section{Indonesia}

Di Negara Republik Indonesia ini berlaku berbagai sistem hukum, yaitu sistem hukum adat, sistem hukum Islam, dan sistem hukum Barat, baik yang berasal dari Eropa kontinental yang disebut civil law maupun yang berasal dari Eropa kepulauan yang dikenal dengan common law atau hukum Anglo Sakson. Sistem hukum Eropa daratan (Civil Law) dibawa oleh penjajah Belanda ke Indonesia pada pertengahan abad ke-19 (1854), yang semula dimaksudkan sebagai pengganti hukum Adat dan hukum Islam, diberlakukan terhadap semua golongan penduduk. Namun karena khawatir penduduk yang beragama Islam akan mengadakan perlawanan terus menerus, maka diberi ruangan sempit untuk "hukum kebiasan" yaitu hukum Adat dan "hukum Agama" bagi penduduk pribumi atau golongan bumi putera. Kini, berdasarkan aturan Peralihan Undang-Undang Dasar 1945, hukum Belanda itu masih tetap berlaku di tanah air Kita. ${ }^{48}$

Jika dibandingkan sistem hukum tersebut, akan jelas bahwa hukum Adat dan hukum Islam mempunyai hubungan yang erat dengan agama, bahkan hukum Islam menjadi bagian dari agama Islam. Sementara itu, sistem hukum yang berasal dari Eropa merupakan hukum yang tidak ada hubungannya dengan agama.

Di Indonesia wasiat diperuntukan untuk anak angkat atau orang tua angkat yang di istilahkan dengan wasiat wajibah, yang tertuang dalam diktum KHI pasal 209. yaitu :

kehilangan hak kewarisan. Memang biasanya seseorang berwasiat untuk cucu yang yatim itu. Tetapi sering pula dia meninggal sebelum melakukannya. Karena undang-undang mengambil alih aturan yang tidak dikenal dalam mazhab-mazhab empat, tetapi menjadi pendapat beberapa ulama lain. Muhamad Abū Zahrah, Syarh Qānun al-Wașiyyah, (Beirut: Dār al-Fikr al-'Arabī, 1978), h. 296-313, khusus wasiat wājibah, h. 314-319.

${ }^{48}$ Mohammad Daud Ali, kedudukan dan Pelaksanaan Hukum Islam dalam Negara Republik Indonesia, dalam Hukum Islam dalam Tatanan Masyarakat Indonesia, Cik Hasan Bisri (Eds) (cet. ke-1; Jakarta : Logos, 1998), h. 39-40. 
(1) Harta peninggalan anak angkat dibagi berdasarkan pasal $176-193$, sedangkan terhadap orang tua angkat yang tidak menerima wasiat diberi wasiat wajibah sebanyak-banyaknya $1 / 3$ dari harta warisan anak angkatnya.

(2) Terhadap anak angkat yang tidak menerima wasiat diberi wasiat wajibah sebanyak-banyaknya $1 / 3$ dari harta warisan orang tua angkatnya. ${ }^{49}$

Tampaknya inisiatif model Pakistan telah masuk ke Indonesia, melalui bagian 4 dari Ordonansi Hukum Keluarga Tahun 1961, negara ini telah memberikan kepada cucu laki-laki maupun perempuan, hak untuk menerima bagian yang sama dengan bagian yang seharusnya diterimakan kepada orang tua mereka yang telah meninggal terlebih dahulu jika orang tua tersebut masih hidup pada saat pembagian warisan.

Untuk warisan cucu di Indonesia tertuang dalam pasal 185 $\mathrm{KHI}$, tetapi tidak menggunakan istilah wasiat wajibah melainkan menggunakan istilah ahli waris pengganti. Bunyi pasal tersebut adalah:

(1) Ahli waris yang meninggal lebih dahulu dari pewaris maka kedudukannya dapat digantikan oleh anaknya, kecuali mereka yang tersebut dalam pasal $173 .^{50}$

(2) Bagian dari ahli waris pengganti tidak boleh melebihi dari bagian waris yang sederajat dengan yang diganti. ${ }^{51}$

Reformasi hukum keluarga yang digunakan di Indonesia sebagian besar tergantung pada hukum Adat. Sesuai dengan

${ }^{49}$ Instruksi Presiden R.I. Nomor I Tahun 1991, Kompilasi ..., h. 94. Bandingkan dengan pasal 5 UU Muslim Personal Pakistan :"dalam keadaan ada anak laki-laki atau perempuan pewaris telah meninggal dunia dan dia meninggalkan keturunan pada saat warisan anak dibagikan, maka anak-anak tersebut menerima bagian yang sama persis dengan bagian yang seharusnya diterima oleh orang tua mereka". Mahmood, Personal Law ..., h. 163.

${ }^{50}$ Pasal 173 yang dimaksud adalah dipersalahkan telah membunuh atau mencoba membunuh atau menganiaya berat para pewaris, dipersalahkan secara memfitnah telah mengajukan pengaduan bahwa pewaris telah mengajukan suatu kejahatan yang diancam dengan hukuman 5 tahun penjara atau hukuman yang lebih berat. Ibid., h. 82 .

${ }^{51}$ Ibid. 
hukum Adat, umum dilakukan oleh keluarga Indonesia untuk mengadopsi anak laki-laki atau perempuan, untuk kemudian dimasukan ke dalam lingkungan keluarga mereka. Dalam masyarakat patrinial seperti masyarakat Batak, masyarakat matrinial Minangkabau, lembaga adopsi sering dihubungkan dengan dominasi politis dari ayah dan ibu dalam keluarga. Lain lagi dalam masyarakat Jawa, adopsi diperbolehkan tidak hanya anak laki-laki tetapi juga terhadap anak perempuan. Dengan pertimbangan-pertimbangan moral sebagai alasan utama dalam pengangkatan anak, misalnya untuk menolong anak yatim, suatu keluarga dapat mengadopsi seorang anak dengan konsekuensi hukum bahwa anak tersebut, baik laki-laki maupun perempuan, akan memperoleh hak yang sama dihadapan hukum sebagai mana anak yang sah. ${ }^{52}$

Berdasar pada praktek hukum yang ada tersebut, maka kemudian para ahli hukum Islam Indonesia merasa berkewajiban untuk menjembatani kesenjangan antara hukum Islam dengan hukum Adat. Maka para ahli hukum Islam Indonesia berusaha untuk mengakomodasikan sistem nilai yang ada dalam kedua hukum dengan jalan menggambil dari institusi wasiat wajib yang berasal dari hukum Islam sebagai sarana untuk menerima fasilitas nilai moral yang ada dibalik praktek adopsi dalam hukum adat. Usaha ini harus dilakukan karena fakta bahwa dalam semua masyarakat yang mempraktekan adopsi tersebut, orang tua angkat selalu memikirkan kesejahteraan dari anak angkatnya ketika mereka sudah meninggal. Inilah ide yang ada dibalik semangat untuk merekonstruksi Kompilasi Hukum Islam sedemikian rupa yang mampu menerjemahkan wasiat wajib sebagai alat untuk memperbolehkan anak angkat untuk mewarisi secara sah harta warisan orang tua angkatnya. ${ }^{53}$ Akomodasi antar dua sistem nilai hukum yang berbeda dalam hal pengangkatan anak tesebut merupakan bukti yang kuat betapa usaha-usaha

${ }^{52}$ Ratno Lukito, Pergumulan..., h. 89-90.

${ }^{53} \mathrm{Ibid}$. 
yang diperlukan senantiasa dilakukan oleh kedua eksponen hukum Islam maupu hukum adat untuk menghindari konflik.

\section{ANALISIS KOMPARATIF}

Sebagaimana maksud dilakukannya pembaruan dalam hukum keluarga, baik di Tunisia, Syria, Mesir dan Indonesia, adalah dalam rangka mengakomodasi tuntunan perubahan mayarakat dengan perubahan zaman, sehingga diperoleh ketetapan-ketetapan hukum yang berlaku bahkan mengikat di dalam masyarakat. Yang pada akhirnya akan mengalami perubahan dari kitab-kitab fikih dengan menambahkan peraturan-peraturan baru-keberanjakan vertical-dengan beberapa negara yang telah mengalami pembaruan hukum dengan menggunakan metode regulatori dan modifikasi yang sebelumnya didahului dengan metode pembaruan intra doctrinal dengan mengambil doktrin dari berbagai mazhab fikih, baik metode takhayyur ${ }^{54}$ maupun talfi ${ }^{55}$, dan pembaruan ekstra doctrinal. ${ }^{56}$

\section{Perbandingan Vertikal}

Terkhusus masalah hukum wasiat, sebetulnya kasus cucu terhijab oleh saudara ayahnya bukan saja menjadi problem masyarakat Indonesia, tetapi menjadi problem seluruh umat Islam di dunia. Sebab kehijaban tersebut ditemukan dalam semua

${ }^{54}$ Takhayyur, yaitu menyeleksi berbagai pendapat mazhab secara eklektik melalui fatwa (judicial direvtiveI). Lihat, Marzuki Wahid dan Rumadi, Fiqh Mazhab Negara, Kritik atas Politik Hukum Islam di Indonesia (Yogyakarta : LKiS, Februari, 2001), h. 90. lain. Ibid.

${ }^{55}$ Talfiq, yaitu menggabungkan mazhab yang satu dengan mazhab yang

${ }^{56}$ Mahmood, Personal..., h. 267-270 ; Intra Doctrinal Reform, yaitu reformasi hukum keluarga Islam yang dilakukan dengan menggabungkan pendapat dari beberapa madzab atau mengambil pendapat lain selain dari madzab utama yang dianut sedangkan Extra Doctrinal Reform, yaitu pembaruan hukum dengan cara memberikan penafsiran yangn sama sekali baru terhadap nas yang ada. Lihat M. Atho Mudzhar, Membaca Gelombang Ijtihad, Antara Tradisi dan Liberasi (Yogyakarta: Titian Ilahi Press, 1998), h. 177. 
mazhab. Praktek pembagian wasiat di negara-negara Muslim tidak semua keadaanya sama. Dan jika dibandingkan dengan ketentuan fikih, telah mengalami beberapa perbedaan bahkan perubahan. Perubahan yang paling signifikan ada pada masalah ketentuan ahli waris yang berhak mendapatkan wasiat, maka adalah logis jika disyaratkan bahwa perolehan itu tidak melebihi sepertiga peninggalan, yang merupakan batas maksimum yang tidak boleh dilampaui oleh wasiat kecuali atas pertimbangan dan izin daripada ahli waris.

Untuk lebih jelasnya, apabila seorang meninggal dan meninggalkan seorang anak laki-laki dan seorang anak laki-laki dari anak laki-laki (ibnu ibnin) yang ayahnya telah meninggal lebih dahulu dari orang yang meninggal pertama, maka anak lakilaki dari anak laki-laki (cucu pancaran laki-laki) itu mendapat bagian yang sedianya akan diterima oleh ayahnya seandainya sang ayah itu masih masih hidup pada waktu meninggalnya orang yang meninggal pertama, dan bagian itu dikurangi hingga tinggal sepertiga karena bagian ayahnya itu melebihi jumlah maksimal yang dibenarkan untuk diwasiatkan. Sedangkan sisanya diambil oleh pamannya. Meskipun cemerlang dan responsif terhadap rasa kemanusiaan yang tinggi dalam memperhatikan kepentingankepentingan para cucu, namun ijtihad ini merupakan pelanggaran terhadap ketentuan-ketentuan kewarisan yang disepakati dalam madzhab empat. ${ }^{57}$

\section{Perbandingan Horizontal}

Sebagaimana yang dijelaskan di atas, masing-masing negara memiliki aturan-aturan sendiri yang tidak persis sama, walaupun ada beberapa kesamaan tetapi tidak telalu signifikan. Istilah wasiat wajib memiikii keganjilan karena wasiat itu secara konseptual bersifat sukarela yang dilawankan dengan ketentuan warisan yang bersifat memaksa. Berdasarkan hal ini, beberapa

${ }^{57}$ Johanes den Heijer dan Syamsul Anwar, Islam, Negara dan Hukum (Jakarta : INIS, 1993), h. 113-134. 
Negara Muslim mengubah aturan yang telah ada dalam kitabkitab fikih, dalam hal ketentuan bagian wasiat bagi cucu yang ditinggal mati oleh orang tuanya. Di negara Syria dan Tunisia mengambil langkah memberikan maksimum sepertiga bagi cucu laki-laki maupun perempuan hanya pada tingkat pertama.

Di Mesir, penggunaan argumentasi secara psikologis agak menyentuh ini biasa dilakukan karena sudah menjadi fitrah manusia untuk merasa kuatir terhadap anak-anak yang ditinggalkannya. Argumen ini telah mendapat dukungan berkat adanya usaha-usaha memasyarakatkan keluarga kecil yang dalam masyarakat Arab dan Islam meniru Barat. Oleh sebab itu, Mesir mengadakan pemecahan masalah terhalangnya cucu mendapat harta wasiat. Pemecahan yang cemerlang yang diberikan undangundang ini tercermin dalam konsep "wasiat wajib" yang didasarkan pada pengandaian bahwa kakek atau nenek yang telah berwasiat untuk cucu-cucunya dengan sejumlah peninggalan yang besarnya sama dengan bagian yang sedianya akan diterima oleh ayah atau ibunya yang telah meninggal semasa hidup kakek atau nenek mereka.

Di Indonesia, melalui Diktum pasal 209 Kompilasi Hukum Islam, memberikan ketentuan yang amat radikal ${ }^{58}$ mengenai anak angkat, dengan menyatakan bahwa orang tua angkat yang tidak mendapat wasiat diberi wasiat wajibah sebanyak-banyaknya sepertiga dari harta peninggalan anak angkatnya ; anak angkat yang tidak menerima wasiat diberi wasiat wajibah sebanyakbanyaknya sepertiga dari harta anak angkatnya. ${ }^{59}$

\section{Perbandingan Diagonal}

Dalam hal hukum wasiat, yang melangkah lebih maju di antara keempat Negara Muslim: Tunisia, Syria, Mesir dan Indonesia ialah Mesir yang memberikan bagian wasiat kepada

${ }^{58}$ Ibid., h. 185.

${ }^{59}$ Instruksi Presiden RI Nomor I Tahun 1991, Kompilasi ..., h. 94. 
cucu persis sama dengan bagian ayah dan ibunya. Juga dalam hal apakah cucu dari pancaran anak laki-laki yang ada pada generasi pertama menerima wasiat, menyusul hal ini berlaku di Tunisia dan Syria yang jauh ketinggalan dibanding dengan di Mesir.

Jika Indonesia dibandingkan dengan ketiga negara tersebut di atas, dapat dikatakan bahwa Indonesia melangkah paling jauh dan radikal, karena memberikan wasiat kepada anak angkat yang sama sekali tidak ada dalam kitab fikih manapun. Hanya perubahan istilah bagi cucu penerima wasiat dengan ahli waris pengganti. Walaupun Indonesia lebih melangkah jauh, akan tetapi untuk undang-ungang hukum keluarga terlengkap terdapat di Mesir.

\section{Metode Pembaruan}

Negara-negara yang menggunakan metode pembaruan Ekstra Doctrinal Reform seperti Syria, cucu yang berhak hanya yang melalui anak-laki-laki, cucu perempuan tidak berhak. Demikian juga dengan Tunisia, menggunakan metode pembaruan Intra Doctrinal Reform, melalui metode Takhayyur, wasiat wajib hanya berlaku untuk cucu (generasi pertama) dan tidak berlaku untuk cucu yang derajatnya lebih rendah, yang mengambil dua pendapat mazhab fikih yakni mazhab Maliki dan Hanafi.

Sebenarnya negara yang mula-mula memperkenalkan hal ini, adalah Mesir dan cukup berani dibandingkan negara Islam lainnya. Melalui hukum waris tahun 1946, Mesir juga menggunakan metode pembaruan Ekstra Doctrinal Reform dengan menyatakan bahwa anak yang meninggal lebih dahulu dan meninggalkan anak maka si cucu itu menggantikan ayahnya dalam mewarisi kakeknya atau neneknya dengan cara wasiat wajibah, banyak harta tidak lebih dari sepertiga.

Adapun yang menetapkan adalah pengadilan, dengan demikian di Mesir telah mengadakan pembaruan dengan metode regulatori sekaligus modifikasi dan juga telah membuat beberapa 
terobosan lain terhadap aturan fikih mazhab yang dianggap sudah tidak memuaskan. Demikian juga dengan di Indonesia, anak angkat yang menerima wasiat harus disahkan di depan sidang pengadilan, walaupun pembaruan di Indonesia ini sama sekali tidak terdapat dalam kitab fikih yang memberikan wasiat kepada anak angkat. Hal ini dipengaruhi oleh hukum Adat yang ada di Indonesia, yang mengakui keabsahan pengangkatan anak. Walaupun demikian, ijtihad ini telah mendapatkan penerimaan yang baik di kalangan ulama-ulama dalam lapangan kajian fikih dan dianggap sebagai contoh ijtihad fikih modern yang sangat menarik dan berpengaruh.

\section{PENUTUP}

Negara yang disebut di atas, yang mayoritas penduduknya adalah Muslim, telah mengadakan pembaruan hukum keluarga yang masih berdasar pada citra Islam, walaupun negara-negara tersebut telah dipengaruhi dengan berbagai sistem hukum, baik hukum Barat maupun hukum Adat yang hidup dalam masyarakat. Di antara ke empat negara di atas, yang mempunyai kodifikasi hukum keluarga yang lengkap adalah Mesir, secara khusus dalam hal hukum wasiat, kodifikasi dan pembaruan hukum keluarga ini telah memperkenalkan konsep-konsep yang belum pernah dikenal sebelumnya dalam fikih Islam.

Mengenai metode yang digunakan dalam pembaruan hukum keluarga tidak hanya untuk merealisasikan kemaslahatan sosial berdasarkan ketentuan syari'at saja, tetapi juga bercampur dengan pengaruh hukum sebagai negara-negara bekas jajahan Barat.

\section{DAFTAR PUSTAKA}

Al-Qur'an dan Terjemahannya.

Abdul, Aziz, Encyclopedi Hukum Islam, Jakarta : PT. Ichtiyar Baru Van Hoeve, jilid 6, 1997. 
Abubakar, Alyasa Ahli Waris Sepertalian Darah Kajian Perbandingan terhadap Penalaran Hazairin dan Penalaran Fikih Mazhab, Jakarta : INIS, 1998.

Ali, Mohammad Daud kedudukan dan Pelaksanaan Hukum Islam dalam Negara Republik Indonesia, dalam Hukum Islam dalam Tatanan Masyarakat Indonesia, Cik Hasan Bisri (Eds), Jakarta : Logos, Cet. I., 1998.

al-Khatib Hasan Ahmad, al-Figh al-Muqaran, Mesir: Dar al-Taklif, 1957.

al-Zuhaili, Wahbah al-Figh al-Islami wa adillatuhu, Beirut: Dar alFikr, Vol. VIII, 1989.

Bearman, Pj (eds), The Encyclopedia of Islam, New Edition, Leiden :Brill, 2000.

Coulson, Hukum Islam Dalam Persfektif Sejarah, (Terj), Hamid Ahmad, Jakarta: P3M cetakan I, 1987.

Edge, Ian dalam Nicholas heer, (Eds), Islamic law and jurisprudensi, wangshinton : University of Wangshinton Press, 1990 .

Esposito, John L. The Oxford Encyclopedia of The Modern Islamic World, New York-Oxford : Oxford University, 1991.

Esposito, John. L. Ensiklopedi Oxford Dunia Islam Modern, Bandung : Mizan, 2000.

Hazairin, Hukum Kewarisan Bilateral menurut Qur'an dan Hadis, buku ke-2. Jakarta : 1964

Heijer, Johanes den, dan Syamsul Anwar, Islam, Negara dan Hukum, Jakarta : INIS, 1993.

Instruksi Presiden R.I. Nomor I Tahun 1991,Kompilasi Hukum Islam di Indonesia, Direktorat Pembinaan Badan Peradilan Agma Direktorat Jenderal Binbaga Depag R.I. Tahun 1998/1999.

Jamil, Fathurrahman Jurnal Dua Bulanan Mimbar Hukum : Aktualisasi Hukum Islam, Nomor 38 Tahun IX. al-Hikmah dan Direktorat : Pembinaan Badan Peradilan Agama Islam, Jakarta, 1998. 
Lapidus, Ira M. Sejarah Sosial Umat Islam, (Terj) Ghufron. A. Mas'ad, Bag. III, Jakarta : Raja Grafindo Parsada, Cet. I., 1999.

Lewis, B. CH. Pellat dan J. Schact, The Encyclopedia of Islam, Leiden : EJ Brill, 1965.

Liebesny, Herbert J. The Law of The Near and Middle East: Readings, Cases, and Materials, Albany : State University of New York Press, 1975.

Lukito, Ratno Pergumulan antara Hukum Islam dan Adat di Indonesia, Jakarta : INIS, 1998.

Mahmasany, Al-Mahamiy Subhiy Al-Mabadi' asy-Syar'iyyah wa alQanuniyyah fi al-Hajr wa an-Nafaqat wa al-Mawaris wa alWashiyyah, Beirut: Dar al-Ilm al-Malayin, 1967.

Mahmood, Tahir Personal Law in Islamic Countries, (History, Text and Comparative Analysis), New Delhi : Academy of Law and Relegion, 1987.

Mahmood, Tahir, Family Law Reform in The Muslim World, Bombay : NM. Tripthi, 1972.

Malik, Imam Muwatha' al-Imam Malik, (terj) Adib Bisri Musthofa, dkk. Semarang : CV. Asy-Syifa, jilid II, Sepetember 1992.

Mudzhar, M. Atho Membaca Gelombang Ijtihad, Antara Tradisi dan Liberasi, Yogyakarta : Titian Ilahi Press, 1998.

Muhammad, Taqiyuddin Abi Bakr ibn kifayatul Akhyar, (terj), Muhamad Rifa'i, dkk. Semarang : Toha Putra, Mei, 1978.

Peretz, Don The Middle East Today, New York : Praeger, 1986.

Powers, David S. Studies in al-Qur'an and Hadith: The Formation of the Islamic Law of Inheritance, terj. Arif Maftuhin, Cet. I, Yogyakarta: LKiS , Agustus 2001.

Sabiq, Sayyid Figh al-Sunnah, Beirut : Dar al-Fikr, Vol III, 1995 (terj)., Mudzakir AS. Bandung: al-Ma'arif, jilid 14, 1996.

Shiddiq, Nourouzzaman, Figh Indonesia, Penggagas dan Gagasannya, Cet. I, Yogyakarta : Pustaka Pelajar, Juni 1997.

Thalib, Sajuti Hukum Kewarisan Islam di Indonesia, Jakarta: Sinar Grafika, Cet. V, Juli, 1995. 
Vol. 8, No.2, Desember 2011: 233-264

Wahid, Marzuki dan Rumadi, Figh Madzhab Negara, Kritik atas Politik Hukum Islam di Indonesia, Yogyakarta : LKiS, Februari 2001.

Zahrah, Abu Muhamad Syarah Qanun al-Washiyyah, Beirut : Dar al-Fikr al-Araby, 1978. 